\title{
CASP6 Gene
}

National Cancer Institute

\section{Source}

National Cancer Institute. CASP6 Gene. NCI Thesaurus. Code C28435.

This gene is involved in the execution of apoptosis. 